\title{
Sequence changes in predicted promoter elements of STKI I/LKB I are unlikely to contribute to Peutz-Jeghers syndrome
} Nicholas CM Hearle*1, Ian Tomlinson ${ }^{2}$, Wendy Lim³, Victoria Murday ${ }^{4}$, Edwin Swarbrick ${ }^{5}$, Guan Lim ${ }^{6}$, Robin Phillips 7 , Peter Lee ${ }^{8}$, John O'Donohue ${ }^{9}$, Richard C Trembath ${ }^{10}$, Patrick J Morrison ${ }^{11}$, Andrew Norman ${ }^{12}$, Rohan Taylor ${ }^{13}$, Shirley Hodgson ${ }^{14}$, Anneke Lucassen ${ }^{15}$ and Richard S Houlston ${ }^{16}$

Address: ${ }^{1}$ Section of Cancer Genetics, Institute of Cancer Research, Sutton, UK, ${ }^{2}$ Molecular and Population Genetics Laboratory, Imperial Cancer Research Fund, London, UK, ${ }^{3}$ Section of Cancer Genetics, Institute of Cancer Research, Sutton, UK, ${ }^{4}$ Dept of Medical Genetics, Yorkhill Hospital, Glasgow, UK, ${ }^{5}$ Dept of Gastroenterology, New Cross Hospital, Wolverhampton, UK, ${ }^{6}$ Dept of Gastroenterology, Epsom General Hospital, UK, ${ }^{7}$ Polyposis Registry, St. Mark's Hospital, Watford Road, Harrow, UK, ${ }^{8}$ Dept of Surgery, Hull Royal Infirmary, UK, ${ }^{9}$ Dept of Gastroenterology, University Hospital Lewisham, London, UK, ${ }^{10}$ Dept of Clinical Genetics, Leicester Royal Infirmary, Leicester, UK, ${ }^{11}$ Department of medical genetics, Belfast City Hospital, UK, ${ }^{12}$ Clinical Genetics Unit, Birmingham Women's Hospital, Birmingham, UK, ${ }^{13}$ Molecular Genetics Unit, St Georges Hospital Medical School, London, UK, ${ }^{14}$ Department of Clinical Genetics, St. Georges Hospital, London, UK, ${ }^{15}$ Wessex Clinical Genetics Service, The Princess Anne Hospital, Southampton, UK and ${ }^{16}$ Section of Cancer Genetics, Institute of Cancer Research, Sutton, UK

Email: Nicholas CM Hearle* - nick.hearle@icr.ac.uk; Ian Tomlinson - wdlim@yahoo.co.uk; Wendy Lim - wdlim@yahoo.co.uk; Victoria Murday - Victoria.Murday@yorkhill.scot.nhs.uk; Edwin Swarbrick - Edwin.swarbrick@rwh-tr.nhs.uk; Guan Lim - guan.lim@epsomsthelier.nhs.uk; Robin Phillips - marie.gun@cancer.org.uk; Peter Lee - peterwrlee@pmc.edu.my;

John O'Donohue - john.o'donohue@uhl.nhs.uk; Richard C Trembath - rtrembath@hgmp.mrc.ac.uk;

Patrick J Morrison - patrick.morrison@bch.n-i.nhs.uk; Andrew Norman - andrew.norman@bwhct.nhs.uk;

Rohan Taylor - R.TAYLOR@sghms.ac.uk; Shirley Hodgson - shodgson@sghms.ac.uk; Anneke Lucassen - A.M.Lucassen@soton.ac.uk; Richard S Houlston - richard.houlston@icr.ac.uk

* Corresponding author

Published: 17 March 2005

BMC Genomics 2005, 6:38 doi:10.1/86/147|-2/64-6-38
Received: 15 February 2005

Accepted: 17 March 2005

This article is available from: http://www.biomedcentral.com/I47I-2/64/6/38

(C) 2005 Hearle et al; licensee BioMed Central Ltd.

This is an Open Access article distributed under the terms of the Creative Commons Attribution License (http://creativecommons.org/licenses/by/2.0), which permits unrestricted use, distribution, and reproduction in any medium, provided the original work is properly cited.

\begin{abstract}
Background: Germline mutations or large-scale deletions in the coding region and splice sites of STK I I/LKB I do not account for all cases of Peutz-Jeghers syndrome (PJS). It is conceivable that, on the basis of data from other diseases, inherited variation in promoter elements of STKI I/LKBI may cause PJS.
\end{abstract}

Results: Phylogenetic foot printing and transcription factor binding site prediction of sequence $5^{\prime}$ to the coding sequence of STKI I/LKBI was performed to identify non-coding sequences of DNA indicative of regulatory elements. A series of 33 PJS cases in whom no mutation in STKI I/LKB I could be identified were screened for sequence changes in the putative promoter defined by nucleotides -1090 to -1472 . Two novel sequence changes were identified, but were found to be present in healthy individuals.

Conclusion: These findings indicate that promoter sequence changes are unlikely to contribute to PJS. 


\section{Background}

Peutz-Jeghers syndrome (PJS; MIM 175200) is a rare autosomal dominant disorder typified by hamartomatous polyposis of the gastrointestinal tract and melanin pigmentation of the oro-facial region [1]. Although germline mutations in the coding sequence of the serine-threonine kinase gene STK11/LKB1 have been found to cause PJS $[2,3]$, such mutations only account for up to $80 \%$ of cases [4-12]. In addition to locus heterogeneity [13] mutations in regulatory sequences of STK11/LKB1 may cause PJS.

Identifying regulatory genomic sequences through functional assays is time consuming and problematic. As natural selection is more likely to tolerate sequence changes in redundant, non-functional sequence than in functionally important sequences, regulatory elements in noncoding sequence will be highly conserved through evolution. Comparison of sequence between both closely related and highly divergent species therefore allows for the identification of non-coding sequence that has a high probability of being important to the regulation of gene transcription. This alternative approach to the identification of promoter elements is termed "phylogenetic foot printing" [14].

Here we describe the phylogenetic foot printing of the $5^{\prime}$ upstream region of STK11/LKB1 and the sequence analysis of this region in a series of PJS cases in whom exonic and splice site mutations in the gene had been excluded.

\section{Results and discussion}

Figure 1 shows the evolutionary conserved region 5' of the coding sequence of STK11 as identified by the phylogenetic foot-printing programs ECR Browser [15] and CONSITE [16]. There was a high degree of concordance between the predictions from the programs. ECR Browser predicted three regions of high conservation upstream of STK11, encompassing nucleotides -981 to -1668 (nucleotide 0 representing the STK11 translation initiation signal). Sixteen transcription factor binding sites (TFBS) predicted by rVista [17] resided between nucleotides 1053 and -1472 . ConSite predicted 27 TFBSs conserved between human and mouse between nucleotides -1090 and -1605. Through the integration of phylogenetic foot printing and TFBS prediction data from ECR browser/ rVista and ConSite, a consensus region containing predicted TFBS positions was identified between nucleotides -1090 to -1472 .

Additional analysis using the TFBS prediction programs Transplorer (Biobase Biological Databases, Wolfenbüttel, Germany) and Proscan v1.7 [18] identified 9 binding sites between nucleotides -1142 and -1724 , and 76 binding sites between nucleotides -881 and -1572 respectively, confirming the presence of regulatory elements within the consensus region. ECR Browser/ rVista and ConSite have previously been shown to correctly identify $88 \%$ and $66 \%$ of TFBS in functionally verified promoter elements respectively $[15,16]$ and it is highly likely, therefore, that the consensus region encompassing nucleotides -1090 to -1472 , contains STK11/LKB1 promoter elements.

DNA from a series of 33 PJS patients that did not harbour germline STK11/LKB1 mutations (mean age at diagnosis 14 years, range 1-38) was studied for mutations in the region between nucleotides -1001 to -1815 , encompassing all TFBSs predicted by rVista and ConSite. Seven of the cases had a documented family history of PJS. The diagnosis of PJS in all cases was based on established criteria [1]. Three sequence changes were identified. The change G $\rightarrow$ $\mathrm{C}$ at position - 1566 was found in four cases (three heterozygotes and one homozygote) and represented a previously documented single nucleotide polymorphism (rs3795061). An additional single nucleotide change at position $-1268(\mathrm{G} \rightarrow \mathrm{T})$ was identified in eight cases (seven heterozygotes and four homozygotes). A single sample of control DNA used as a sequence reference was also found to be homozygous for the change. Finally, a two base pair deletion coupled with a single base pair insertion at position -1709 (n-1709insTdelCC) was identified in one case. A series of healthy population controls ( $n=92$ ) was screened by High Performance Liquid Chromatography (HPLC) and one individual (1/92) was found to harbour the sequence change. None of these three sequence changes identified were therefore deemed to be potentially pathogenic.

There is a high degree of redundancy in promoter elements of genes, however point mutations in promoter regions of PTEN and MLH1 have been reported to be disease causing $[19,20]$. To investigate the possibility of large-scale deletions or insertions undetectable by straightforward PCR primers P1Fwd and P3Rev were used to amplify an $814 \mathrm{bp}$ fragment with products visualised on a $2 \%$ agarose gel. No large-scale deletions or insertions were detected in any of the patients.

\section{Conclusion}

As understanding of the contribution of coding sequence changes to disease becomes clearer, attention will focus on regulatory elements of genes. Phylogenetic foot printing using programs such as ECR browser and ConSite present potentially powerful tools in identifying regulatory elements, enabling the analysis of these sequences without time consuming functional studies. Although the efficiency of in-silico delineation of promoter elements has not been rigorously evaluated, ECR Browser/ rVista and ConSite have been shown to correctly identify $88 \%$ and $66 \%$ of TFBS respectively $[15,16]$. On the basis of our findings, however, it appears unlikely (upper $95 \%$ 


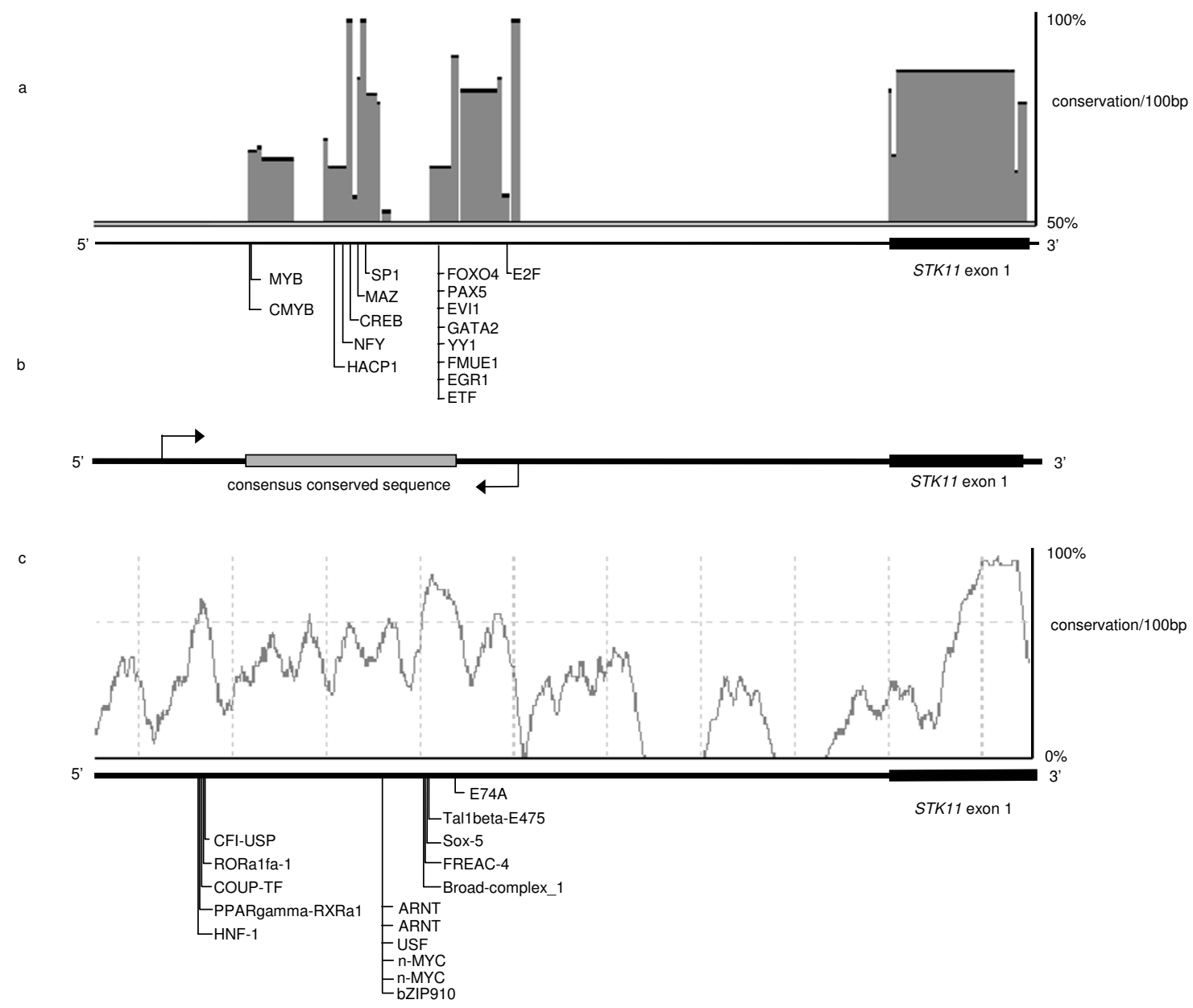

\section{Figure I}

in-silico identification of the putative STKI I /LKBI promoter. (a) ECR browser output. Regions of high sequence conservation 5 ' of STKI I exon I are annotated with transcription factor binding sites as predicted by rVista v2.0 between nucleotides -98I to -1668. (c) ConSite output. Sequence of high conservation is annotated with predicted transcription factor binding sites (TFBS) as predicted by the JASPER TFBS database between nucleotides - I 104 to - I6I3. (b) Ideogram showing consensus conserved region, defined at the $3^{\prime}$ end by the E74A TFBS predicted ConSite, and at the 5 ' end by the CMYB TFBS predicted by rVista. Arrows indicate the genomic sequence analysed.

confidence interval, prevalence; $9 \%$ ) that mutations in the promoter region of STK11/LKB1 are responsible for PJS cases not attributable to exonic sequence changes.

\section{Methods}

\section{Bioinformatics}

Phylogenetic foot printing of $3 \mathrm{~Kb}$ of sequence upstream of human and mouse STK11/LKB1 (NT_011255) was performed using the promoter predication programs ECR Browser [15] and CONSITE [16]. For both programs a conservation cut-off of $70 \%$ identity over 100 base pairs was adopted, in accordance with published criteria $[21,22]$. Regions identified by ECR Browser with greater than $70 \%$ conservation were analysed using the TFBS prediction program rVista v2.0 [17]. Conserved regions identified by ConSite were annotated with TFBSs based on the JASPAR database [23] and links provide sequence information. Further analysis was carried out using the TFBS prediction programs Proscan version1.7 [18] and Transplorer (Biobase Biological Databases, Wolfenbüttel, Ger- 
many). The promoters and TFBS predicted by each program were aligned to delineate a consensus region indicative of a putative promoter.

\section{Mutational analysis}

The possession of germline mutations in STK11/LKB1, including a large-scale deletion of the gene, was excluded using methods previously described [24]. Mutational analysis of the minimal consensus conserved region was carried out by direct DNA sequencing in both directions using the BigDye v3.1 Terminator Cycle Sequencing Ready Reaction Kit in conjunction with an ABI3100 semiautomated genetic analyser (Applied Biosystems, Foster City, USA). Overlapping oligonucleotides amplifying three fragments spanning the region were designed using the Primer3 program [25]: P1Fwd - GCACAGGAGGGTTCAATATTTTC, P1Rev - TTGCGGACCTGGAAGGAG, P2Fwd - ACTGGAATTGGCCACTTTGT, P2Rev - GATACAGCGCGCTCATTG, P3Fwd - GTCTCCCCATGCCTGCTTC, P3Rev - GGCCCAGCCCATCCAAGG. Predicted PCR products were subjected to searches of the genome using the BLAST program [26] to confirm specificity. Chromatograms were analysed by two independent researchers using the programs Chromas [27] and MutationSurveyor (SoftGenetics, State College, USA). High performance liquid chromatography was performed using the WAVE system (Transgenomics, Omaha, USA).

\section{Authors' contributions}

NCMH performed all bioinformatical and molecular studies and drafted the manuscript. IT, WL, VM, ES, GL, RP, PL, JO, RT, PJM, AN, RCT, SH and AL contributed cases of PJS to the study. RSH conceived the study and drafted the manuscript, and participated in the study's design and coordination. All authors read and approved the final manuscript.

\section{References}

I. Tomlinson IP, Houlston RS: Peutz-Jeghers syndrome.J Med Genet 1997, 34:1007-10II.

2. Hemminki A, Markie D, Tomlinson I, Avizienyte E, Roth S, Loukola A, Bignell G, Warren W, Aminoff M, Hoglund P, Jarvinen H, Kristo P, Pelin K, Ridanpaa M, Salovaara R, Toro T, Bodmer W, Olschwang S, Olsen AS, Stratton MR, de la CA, Aaltonen LA: A serine/threonine kinase gene defective in Peutz-Jeghers syndrome. Nature |998, 391:|84-|87.

3. Jenne DE, Reimann H, Nezu J, Friedel W, Loff S, Jeschke R, Muller O, Back W, Zimmer M: Peutz-Jeghers syndrome is caused by mutations in a novel serine threonine kinase. Nat Genet 1998, 1 8:38-43.

4. Boardman LA, Couch FJ, Burgart LJ, Schwartz D, Berry R, McDonnell SK, Schaid DJ, Hartmann LC, Schroeder JJ, Stratakis CA, Thibodeau SN: Genetic heterogeneity in Peutz-Jeghers syndrome. Hum Mutat 2000, 16:23-30.

5. Jiang CY, Esufali S, Berk T, Gallinger S, Cohen Z, Tobi M, Redston M, Bapat B: STK I I/LKB I germline mutations are not identified in most Peutz-Jeghers syndrome patients. Clin Genet 1999, 56:|36-|4I.

6. Mehenni H, Gehrig C, Nezu J, Oku A, Shimane M, Rossier C, Guex N, Blouin JL, Scott HS, Antonarakis SE: Loss of LKB I kinase activity in Peutz-Jeghers syndrome, and evidence for allelic and locus heterogeneity. Am J Hum Genet 1998, 63: I64I-I650.
7. Nakagawa H, Koyama K, Miyoshi Y, Ando H, Baba S, Watatani M, Yasutomi M, Matsuura N, Monden M, Nakamura $Y$ : Nine novel germline mutations of STKI I in ten families with Peutz-Jeghers syndrome. Hum Genet 1998, I03: I68-172.

8. Olschwang S, Markie D, Seal S, Neale K, Phillips R, Cottrell S, Ellis I, Hodgson S, Zauber P, Spigelman A, Iwama T, Loff S, McKeown C, Marchese C, Sampson J, Davies S, Talbot I, Wyke J, Thomas G, Bodmer W, Hemminki A, Avizienyte E, de la CA, Aaltonen L, Tomlinson I, .: Peutz-Jeghers disease: most, but not all, families are compatible with linkage to I9p I 3.3. J Med Genet 1998, 35:42-44.

9. Wang ZJ, Churchman M, Avizienyte E, McKeown C, Davies S, Evans DG, Ferguson A, Ellis I, Xu WH, Yan ZY, Aaltonen LA, Tomlinson IP: Germline mutations of the LKBI (STKII) gene in PeutzJeghers patients. J Med Genet 1999, 36:365-368.

10. Westerman AM, Entius MM, Boor PP, Koole R, de Baar E, Offerhaus GJ, Lubinski J, Lindhout D, Halley DJ, De Rooij FW, Wilson JH: Novel mutations in the LKBI/STK I I gene in Dutch Peutz-Jeghers families. Hum Mutat 1999, I 3:476-48I.

II. Ylikorkala A, Avizienyte E, Tomlinson IP, Tiainen M, Roth S, Loukola A, Hemminki A, Johansson M, Sistonen P, Markie D, Neale K, Phillips R, Zauber P, Twama T, Sampson J, Jarvinen H, Makela TP, Aaltonen LA: Mutations and impaired function of LKB I in familial and non-familial Peutz-Jeghers syndrome and a sporadic testicular cancer. Hum Mol Genet I999, 8:45-5I.

12. Yoon KA, Ku JL, Choi HS, Heo SC, Jeong SY, Park YJ, Kim NK, Kim JC, Jung PM, Park JG: Germline mutations of the STKI I gene in Korean Peutz-Jeghers syndrome patients. Br J Cancer 2000, 82:1403-1406.

13. Mehenni H, Blouin JL, Radhakrishna U, Bhardwaj SS, Bhardwaj K, Dixit VB, Richards KF, Bermejo-Fenoll A, Leal AS, Raval RC, Antonarakis SE: Peutz-Jeghers syndrome: confirmation of linkage to chromosome $19 \mathrm{p} / 3.3$ and identification of a potential second locus, on I 9q I3.4. Am J Hum Genet I997, 6 I: I 327-I334.

14. Tagle DA, Koop BF, Goodman M, Slightom JL, Hess DL, Jones RT: Embryonic epsilon and gamma globin genes of a prosimian primate (Galago crassicaudatus). Nucleotide and amino acid sequences, developmental regulation and phylogenetic footprints. J Mol Biol 1988, 203:439-455.

15. Ovcharenko I, Nobrega MA, Loots GG, Stubbs L: ECR Browser: a tool for visualizing and accessing data from comparisons of multiple vertebrate genomes. Nucleic Acids Res 2004, 32:W280-W286.

16. Lenhard B, Sandelin A, Mendoza L, Engstrom P, Jareborg N, Wasserman WW: Identification of conserved regulatory elements by comparative genome analysis. J Biol 2003, 2: 13.

17. Loots GG, Ovcharenko I, Pachter L, Dubchak I, Rubin EM: rVista for comparative sequence-based discovery of functional transcription factor binding sites. Genome Res 2002, I 2:832-839.

18. Prestidge DS: Predicting Pol II promotor sequences using transcription factor binding sites. J Mol Biol 1995, 23:923-932 [http://bimas.dert.nih.gov/molbio/proscan/].

19. Zhou XP, Waite KA, Pilarski R, Hampel H, Fernandez MJ, Bos C, Dasouki M, Feldman GL, Greenberg LA, Ivanovich J, Matloff E, Patterson A, Pierpont ME, Russo D, Nassif NT, Eng C: Germline PTEN promoter mutations and deletions in Cowden/BannayanRiley-Ruvalcaba syndrome result in aberrant PTEN protein and dysregulation of the phosphoinositol-3-kinase/Akt pathway. Am J Hum Genet 2003, 73:404-4II.

20. Green RC, Green AG, Simms M, Pater A, Robb JD, Green JS: Germline hMLHI promoter mutation in a Newfoundland HNPCC kindred. Clin Genet 2003, 64:220-227.

21. Loots GG, Locksley RM, Blankespoor CM, Wang ZE, Miller W, Rubin $E M$, Frazer KA: Identification of a coordinate regulator of interleukins 4,13 , and 5 by cross-species sequence comparisons. Science 2000, 288: I36-I40.

22. Nobrega MA, Ovcharenko I, Afzal V, Rubin EM: Scanning human gene deserts for long-range enhancers. Science 2003, 302:4I3.

23. Sandelin A, Alkema W, Engstrom P, Wasserman WW, Lenhard B: JASPAR: an open-access database for eukaryotic transcription factor binding profiles. Nucleic Acids Res 2004, 32 Database issue:D91-D94.

24. Prestridge DS: Predicting Pol II promoter sequences using transcription factor binding sites. J Mol Biol 1995, 249:923-932.

25. Lim W, Hearle N, Shah B, Murday V, Hodgson SV, Lucassen A, Eccles D, Talbot I, Neale K, Lim AG, O'Donohue J, Donaldson A, Macdonald RC, Young ID, Robinson MH, Lee PW, Stoodley BJ, Tomlinson I, 
Alderson D, Holbrook AG, Vyas S, Swarbrick ET, Lewis AA, Phillips RK, Houlston RS: Further observations on LKB I/STKI I status and cancer risk in Peutz-Jeghers syndrome. Br J Cancer 2003, 89:308-3।3.

26. Primer 3

[http://frodo.wi.mit.edu/cgi-bin/primer3/ primer3 www.cgi]

27. NCBI BLAST [http://www.ncbi.nlm.nih.gov/BLAST/]

28. Chromas [http://www.technelysium.com.au]

Publish with Biomed Central and every scientist can read your work free of charge

"BioMed Central will be the most significant development for disseminating the results of biomedical research in our lifetime. " Sir Paul Nurse, Cancer Research UK

Your research papers will be:

- available free of charge to the entire biomedical community

- peer reviewed and published immediately upon acceptance

- cited in PubMed and archived on PubMed Central

- yours - you keep the copyright

Submit your manuscript here:

http://www.biomedcentral.com/info/publishing_adv.asp 